\title{
Isohaemagglutinins anti-A and anti-B in rheumatoid arthritis and ankylosing spondylitis
}

\author{
L. KORNSTAD, D. GULDBERG, AND A. M. G. KORNSTAD \\ From the National Blood Group Reference Laboratory and Immunopathology Laboratory, National Institute \\ of Public Health, and Oslo Sanitetsforening Hospital for Rheumatic Diseases, Oslo, Norway
}

It is well known that rheumatoid arthritis (RA) differs from ankylosing spondylitis (AS) in many immunological qualities. Particularly striking is the dissimilar occurrence of rheumatoid factor, but there is also a significant difference in the incidence of other autoantibodies. Antinuclear antibodies and also thyroid antibodies (Kornstad and Kornstad, 1964) are found more frequently in RA than in AS.

It therefore seemed to be of interest to examine whether the increased immunological reactivity of RA patients would be expressed not only in the incidence of 'pathological' antibodies, but also in an increased formation of 'naturally occurring' antibodies. For this purpose a study of the regularly occurring isoagglutinins of the ABO blood group system seemed suitable.

Our knowledge of the effect of various diseases on the production of isohaemagglutinins is limited. Most studies of this kind have keen concerned with various malignant diseases of the haematopoietic tissue or the reticuloendothelial system (Schiff and Mendlowicz, 1926; Zündel, 1933; Davidsohn, 1938; Teitelbaum, Wiener, and Desforges, 1959; Geyer, Keibl, and Speiser, 1960; Fairley, and Akers, 1962; Shohl, Morrison, Fahey, and Schmidt, 1962; Libánsky and Kout, 1964).

Much less is known about the isoagglutinins in rheumatic diseases. The only study in this field is the important investigation of Rawson, Abelson, and McCarty (1961) on serum fractions from 39 RA patients. To extend their studies on RA patients and to compare the isohaemagglutinin levels in RA and AS, we took the opportunity to titrate the serum samples obtained during an investigation of the blood group distribution in RA and AS (Kornstad, Kornstad, and Guldterg, 1965, 1968).

\section{Material and methods}

Blood samples were obtained from patients with definite or classical rheumatoid arthritis according to the criteria of the American Rheumatism Association, and from patients suffering from ankylosing spondylitis according to the criteria described by Kåss (1968). All the patients had been examined at Oslo Sanitetsforening Hospital for Rheumatic Diseases, most of them as in-patients. Besides the blood samples from the two studies mentioned above, some RA and AS samples originally submitted for the determination of thyroid antibodies (Kornstad and Kornstad, 1964) were also titrated for their content of anti-A and/or anti-B. The present RA series thus consists of a total of 129 group A, 21 group B, and 92 group $O$ persons. Among the 242 patients were 185 women and 57 men, giving a sex ratio of $3 \cdot 2$ women to 1 man. Their average age was 55 years $(54 \cdot 5$ years for the women and $56 \cdot 4$ years for the men).

The total number of AS sera titrated were 111 group A, 27 group B, and 82 group $O$. Among the 220 patients were 51 women and 169 men, giving a sex ratio roughly the reverse of that of the RA series, 1 woman to $3 \cdot 3$ men. The average age was $40 \cdot 8$ years $(40 \cdot 6$ years for the men and $41 \cdot 7$ for the women).

The sera were titrated in 0.9 per cent. saline. After an initial dilution of $1: 5$ had been made, a second pipette was used for the further two-fold serial dilutions. Each tube contained $0.2 \mathrm{ml}$. of the serum dilution plus $0.2 \mathrm{ml}$. of a 1/4 per cent. suspension of washed $A_{1}$ or $B$ cells in saline. The mixture was incubated overnight at $4^{\circ} \mathrm{C}$. and thereafter for 1 hour at room temperature. The agglutination reactions were read macroscopically. Of all the sera examined only one gave a negative reaction at the $1: 5$ dilution, and this serum gave a weakly positive reaction at a dilution of $1: 2 \cdot 5$.

As it is well known that minor differences may result when a serum is titrated by different technicians, all the 462 sera of our series were titrated by the same highlyskilled operator.

\section{Results}

Before the findings in these series of patients are presented, it is necessary to draw attention to some features of the isohaemagglutinin distribution in normal populations. A careful analysis of the isoagglutinin findings in the normal Norwegian population has teen performed by Hartmann (unpublished observations). His series comprised 11,422 
persons $(10,071$ men and 1,351 women). He found that, when $A_{1}$ cells were used for the titrations, the average anti-A titres were significantly higher than the average anti-B titres. This implies that the anti-A and anti-B titres in our patients have to be considered separately. Hartmann found that the anti-B titres in $A_{1}$ and $A_{2}$ persons were in good agreement, and we therefore saw no reason to split our group $A$ series. Nor was there in Hartmann's study any significant difference between the anti-A titres of group $B$ and $O$ persons, or between the anti-B of $A$ and $O$ persons. However, there is evidence that a significant proportion of the isoagglutinin molecules in group $O$ persons can belong to the $\gamma \mathrm{G}$ class of immunoglobulins, whereas in group $A$ and $B$ persons the $\gamma \mathrm{M}$ class prevails. The technique used in our study is more sensitive for the demonstration of $\gamma \mathbf{M}$ agglutinins. We therefore felt that the antibody titres of the different main $\mathrm{ABO}$ groups should be considered separately.

The results of the isoagglutinin titrations in RA and AS patients are shown in Figs 1 to 4 (opposite).

The values are given in titration steps, with the lowest titre observed $(1: 2 \cdot 5)$ called 'titration step 1', the highest $(1: 1,280)$ 'titration step 10'.

In all the four antibody categories, the isoagglutinins show a 'shift to the left' in RA as compared with AS. Table I gives the number of titrations in each group and the average titration steps. It will be seen that for the three groups O/anti-A, $\mathrm{O} /$ Anti-B, and $\mathrm{A} /$ anti-B the differences between the averages for AS and RA are about four times their standard error, i.e. the observed differences are highly significant $(P<0.001)$. In blood group $B$ the observed difference is not statistically significant. However, the number of patients belonging to this group is small, as expected from the low incidence of blood group B in the general Norwegian population.

In evaluating the present findings it is necessary to keep in mind that the two patient groups are not identical in sex and age distribution. In the RA patients the sex ratio is more than 3 women to $1 \mathrm{man}$, in AS about the reverse. Moreover, the average age is lower in the AS than in the RA patients. The effect of these variables on the isoagglutinins in the normal population were analysed by Hartmann. In all blood groups he found a fall in the average agglutinin values with increasing age. From age 20 to age 65 the reduction was about 0.75 titration step in men, and slightly less than 0.5 step in women. From age 41 (the average of our AS series) to age 55 (the average of our RA series) the average titres fell by only 0.2 step in men, and only 0.15 step in women. The difference in age distribution is therefore not sufficient to explain the difference in isoagglutinin levels between the two groups of patients observed in our study.

From studies of normal populations it is known that the average agglutinin titres in all $\mathrm{ABO}$ blood groups is higher in women than in men. In Hartmann's study the difference increased from about 0.5 titration step at age 20 to about 0.8 step at age 65. At age 41 the difference was about $2 / 3$ titration step, at age 55 about $3 / 4$. This implies that, if a correction for the difference in age and sex distribution were made in our patient series, the difference between AS and RA would be even more marked than that shown in Figs 1 to 4 and Table I.

Table I shows that there is no difference in the anti-A of group $O$ and $B$, and only a very slight difference in the anti-B titres of group $O$ and $A$

Table I Average isoagglutinin values in AS and RA patients of different ABO blood groups

\begin{tabular}{|c|c|c|c|c|c|c|c|c|c|}
\hline \multirow[b]{2}{*}{$\begin{array}{l}\text { Blood group } \\
\text { |Agglutinin }\end{array}$} & \multicolumn{3}{|c|}{ Ankylosing spondylitis } & \multicolumn{3}{|c|}{ Rheumatoid arthritis } & \multirow[b]{2}{*}{$\begin{array}{l}\text { Difference } \\
A S-R A\end{array}$} & \multirow[b]{2}{*}{$\begin{array}{l}\text { S.E. } \\
\text { diff. }\end{array}$} & \multirow[b]{2}{*}{$\begin{array}{l}\text { Diff. } \\
A S-R A \\
\div S . E . \text { diff. }\end{array}$} \\
\hline & $\begin{array}{l}\text { No. } \\
\text { examined }\end{array}$ & $\begin{array}{l}\text { Average } \\
\text { titration } \\
\text { step }\end{array}$ & S.D. & $\begin{array}{l}\text { No. } \\
\text { examined }\end{array}$ & $\begin{array}{l}\text { Average } \\
\text { titration } \\
\text { step }\end{array}$ & S.D. & & & \\
\hline B/anti-A & 27 & $6 \cdot 48$ & 0.92 & 21 & $6 \cdot 09$ & $0 \cdot 81$ & $0 \cdot 39$ & $0 \cdot 25$ & $1 \cdot 54$ \\
\hline O/anti-A & 82 & $6 \cdot 54$ & 0.87 & 92 & $6 \cdot 04$ & $0 \cdot 82$ & 0.49 & $0 \cdot 13$ & $3 \cdot 83$ \\
\hline O/anti-B & 82 & $6 \cdot 12$ & 0.87 & 92 & $5 \cdot 46$ & $1 \cdot 14$ & 0.66 & $0 \cdot 15$ & $4 \cdot 35$ \\
\hline A/anti-B & 111 & $5 \cdot 89$ & $1 \cdot 02$ & 129 & $5 \cdot 32$ & $1 \cdot 08$ & $0 \cdot 57$ & $0 \cdot 14$ & $4 \cdot 22$ \\
\hline
\end{tabular}



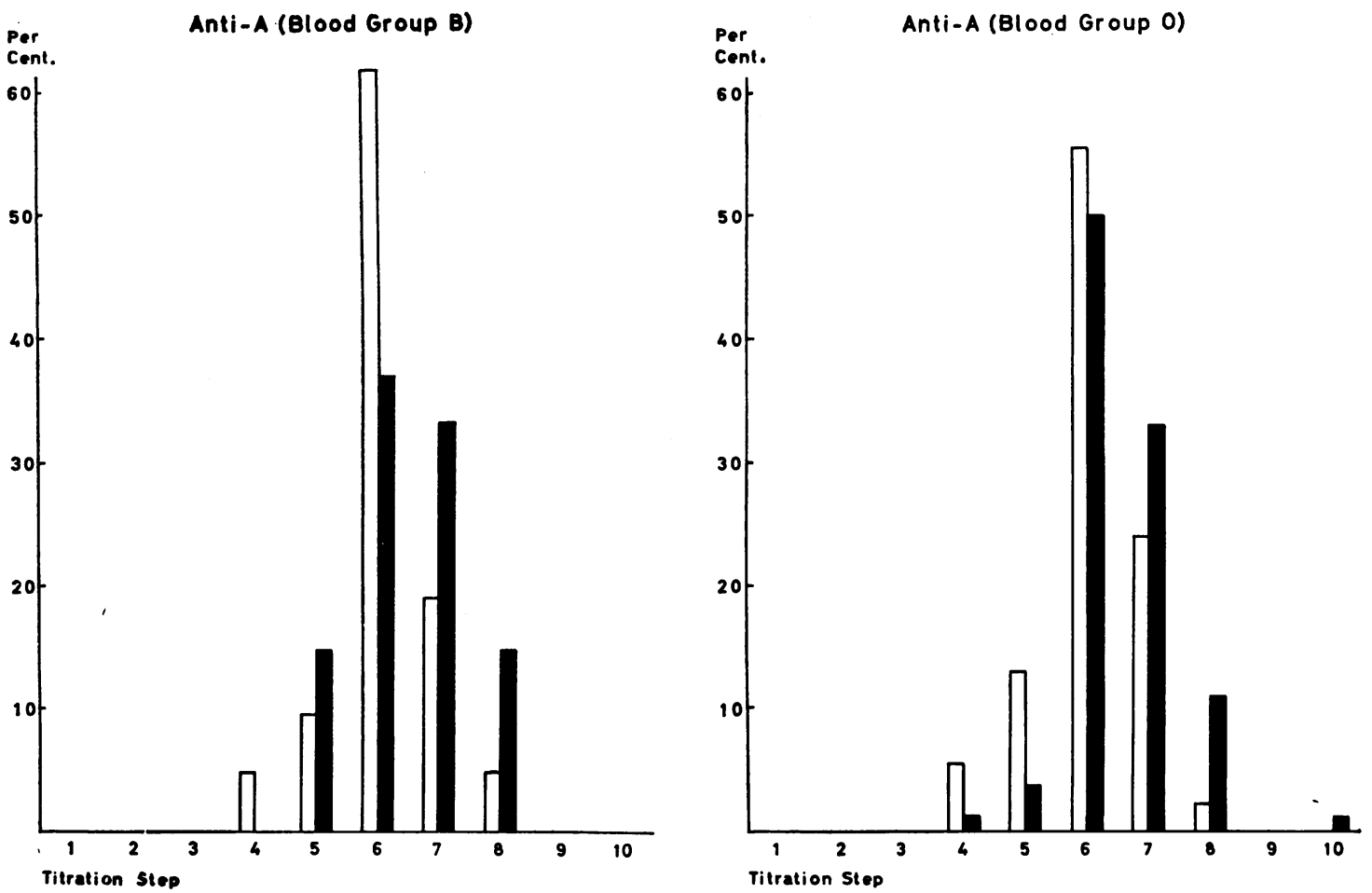

Anti-B (Blood Group 0)

Anti-B (Blood Group A)
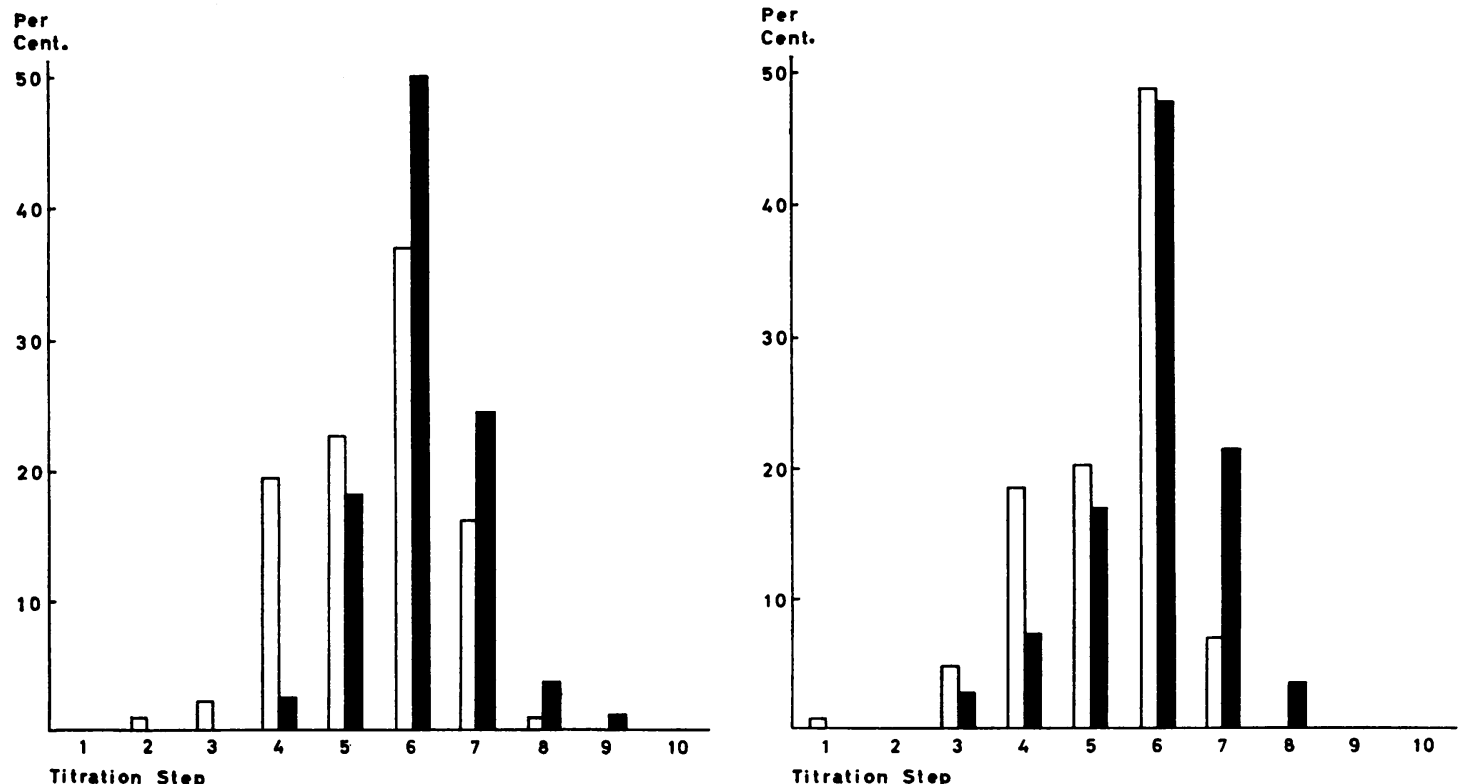

FIGS 1 TO 4 Distribution of isohaemagglutinin activity in patients suffering from rheumatoid arthritis and ankylosing spondylitis.

RA patients: white columns. AS patients: black columns. 
persons in each group of patients. Pooling of the anti-B titrations in group $\mathrm{O}$ and $\mathrm{A}$ patients would give a sufficiently high number of titrations to permit a separate consideration of male and female patients. The results of this analysis are shown in Figs 5 and 6 and Table II. For both sexes the observed difference in titres between AS and RA is statistically significant. For the male patients the ratio between the observed difference and its standard error corresponds to $P$ about 0.003 , for the female patients $P$ is well below 0.001 .

\section{Discussion}

Among the 221 anti-B titrations in our RA patients, there were ten with a titre of 10 or lower. With the

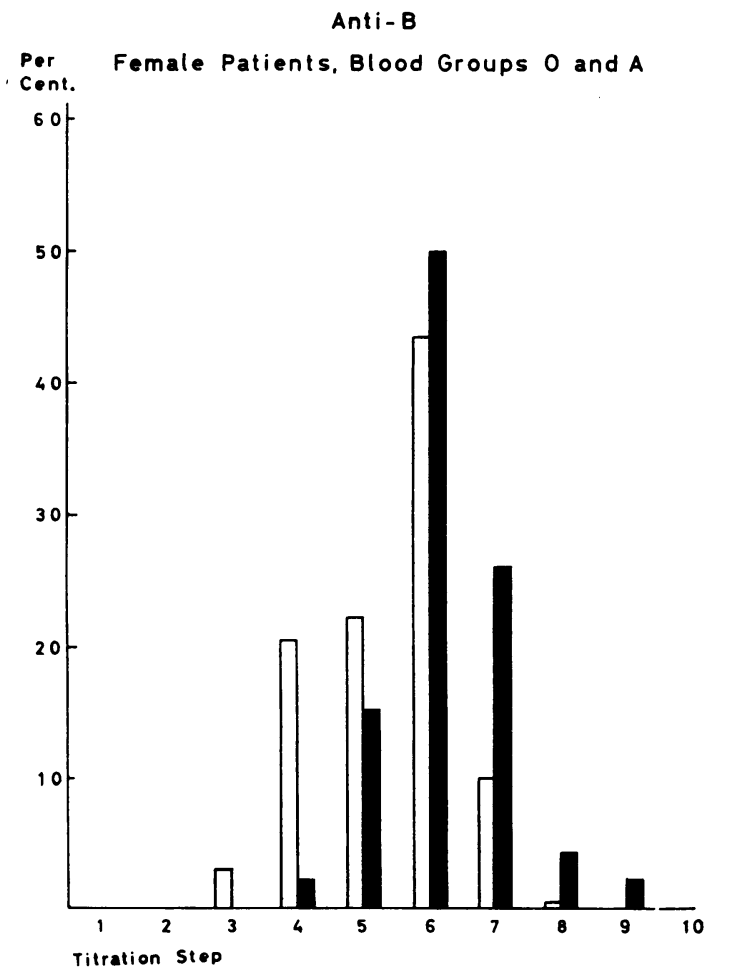

technique used, it is very rare to find values so low among normal persons. It is, therefore, very likely that the observed difference between AS and RA is caused by a reduction of the agglutinin titres in RA, and not by an increase in AS.

Rawson and others (1961) in studying three fractions obtained by separation of serum on DEAE cellulose columns, found that after 'stimulation with incompatible blood group substance, group $\mathrm{O}$ rheumatoids have consistently lower isohaemagglutinin titres than do normal subjects of the same blood group'. Before specific stimulation an essentially similar pattern was noted, although less pronounced. However, in group A and B persons, the titres of none of their serum fractions from RA

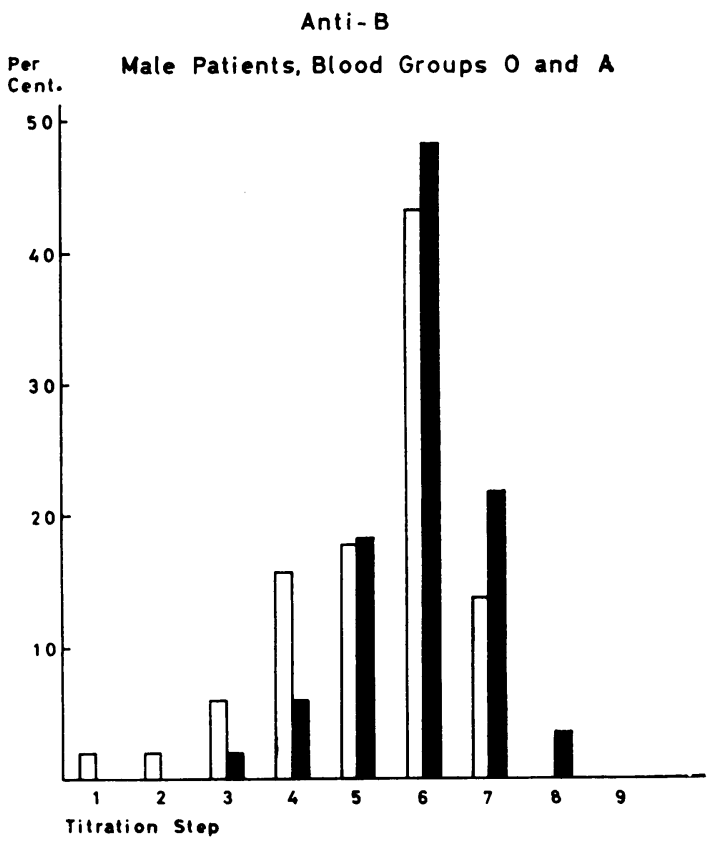

FIGS 5 AND 6 Distribution of anti-B titres in female and male patients of blood groups $O$ and $A$.

$R A$ patients: white columns. AS patients: black columns.

Table II Titration of anti-B in sera from group $O$ and $A$ patients

\begin{tabular}{|c|c|c|c|c|c|c|c|c|c|}
\hline \multirow[b]{2}{*}{$\operatorname{Sex}$} & \multicolumn{3}{|c|}{ Ankylosing spondylitis } & \multicolumn{3}{|c|}{ Rheumatoid arthritis } & \multirow[b]{2}{*}{$\begin{array}{l}\text { Difference } \\
A S-R A\end{array}$} & \multirow[b]{2}{*}{$\begin{array}{l}\text { S.E. } \\
\text { diff. }\end{array}$} & \multirow[b]{2}{*}{$\begin{array}{l}\text { Diff. } \\
A S-R A \\
\div S . E . \text { diff }\end{array}$} \\
\hline & $\begin{array}{l}\text { No. } \\
\text { examined }\end{array}$ & $\begin{array}{l}\text { Average } \\
\text { titration } \\
\text { step }\end{array}$ & S.D. & $\begin{array}{l}\text { No. } \\
\text { examined }\end{array}$ & $\begin{array}{l}\text { Average } \\
\text { titration } \\
\text { step }\end{array}$ & S.D. & & & \\
\hline Female & 46 & $6 \cdot 22$ & 0.91 & 170 & $5 \cdot 39$ & $1 \cdot 03$ & $0 \cdot 83$ & $0 \cdot 15$ & $5 \cdot 34$ \\
\hline Male & 147 & $5 \cdot 92$ & 0.98 & 51 & $5 \cdot 29$ & $1 \cdot 33$ & 0.62 & $0 \cdot 20$ & $3 \cdot 07$ \\
\hline
\end{tabular}

S.D. = Standard deviation. S.E. diff. = Standard error of difference. 
patients differed significantly from those of corresponding normal subjects.

Our findings are in agreement with those of Rawson and others in RA patients belonging to blood group $O$. In our study, however, a reduction in the isoagglutinin levels of about the same magnitude is also observed in RA patients of blood groups A and B. It is difficult to explain this discrepancy. A direct comparison is somewhat difficult because the titrations by Rawson and others were performed on serum fractions, ours on whole serum. Furthermore, in the study of Rawson and others, the anti-A and anti-B titres in group $O$ persons were pooled, and so were the isoagglutinin titres for group $\mathbf{A}$ and $B$ persons. A deviation of the agglutinin titres in group A and B patients may have been missed because of the limited number of patients examined: there were fourteen RA patients of blood group A, five of group $B$.

The cause of the lower isoagglutinin values in RA than in AS is unknown. There may be a reduced isoagglutinin production in RA; or there may be an accelerated elimination.

A number of the RA patients have, of course, been receiving corticosteroid treatment for some time and this might have given an immunosuppressive effect with a reduced isoagglutinin production. However, it is known that $\mathrm{Rh}$ immunized women have been treated with large doses of corticosteroids for long periods in an attempt to mitigate the severity of the haemolytic disease in their foetuses. The treatment not only failed to reduce the titres of the existing isoantibodies, but also seemed to fail to suppress a secondary response to the corresponding antigen (Mollison, 1967). It therefore seems unlikely that the more moderate doses usually employed in the treatment of RA patients have caused the low isoagglutinin levels.

In this connexion we also have to call attention to the increased incidence of autoantibodies in RA.
It might indeed seem as if the immune system in RA is so far engaged in producing 'pathological antibodies' that a reduced capacity remains for the formation of the normal, naturally occurring isoantibodies. A similar reduction in the isoagglutinins has been demonstrated in some malignant diseases involving the immune apparatus, particularly in chronic lymphatic leukaemia, less marked in lymphosarcoma and multiple myeloma (Teitelbaum and others, 1959; Geyer and others, 1960, Fairley and Akers, 1962; Shohl and others, 1962; Libánsky and Kout, 1964).

An accelerated elimination of the haemagglutinins might theoretically be caused by the formation of a complex between rheumatoid factor and the $\gamma \mathbf{G}$ fraction of the isoantibodies. This explanation is not very likely because the serological technique used is more sensitive for detecting $\gamma \mathbf{M}$ than $\gamma \mathrm{G}$ isoagglutinins.

\section{Summary}

The anti-A and anti-B haemagglutinins have been determined in sera from 242 patients with rheumatoid arthritis and 220 patients with ankylosing spondylitis The titrations were done in saline. A comparison of the isoagglutinin levels in the two groups of patients was performed for

(1) Anti-B in persons of blood group A;

(2) Anti-B in group $O$;

(3) Anti-A in group $O$;

(4) Anti-A in group B.

In each of these four cases there was a lower average titre in rheumatoid arthritis patients than in ankylosing spondylitis patients. The difference is most probably due to a reduction in the isoagglutinin levels in rheumatoid arthritis. The reduction is the more remarkable if the increased occurrence of various autoantibodies in this disease is considered.

\section{References}

Davidsohn, I. (1938) Amer. J. clin. Path., 8, 179 (Isoagglutinin titers in serum disease, in leukemias, in infectious mononucleosis, and after blood transfusions).

Fairley, G. H., AND Akers, R. J. (1962) Brit. J. Haemat., 8, 375 (Antibodies to blood group A and B substances in reticuloses).

GeYer, G., KeIBL, E., AND SPEISER, P., (1960) 'Erworbener Isoagglutininmangel bei Blutkrankheiten', in 'Proc. VII Congr. Europ. Soc. Haemat., London, 1959', pt. 2, p. 543. Karger, Basel.

HaRTMANN, O. (Unpublished observations).

KÅss, E. (1968) Acta rheum. scand., 14, 197 (Diagnostic criteria in spondylarthritis ankylopoietica).

Kornstad, A. M. G., Kornstad, L., AND GuldBerg, D. (1965) Nature (Lond.), 206, 836 (Blood groups in rheumatoid arthritis).

$\longrightarrow,-,-$ (1968) Ann. rheum. Dis., 27, 472 (Blood groups in ankylosing spondylitis).

KORNSTAD, L., AND KoRnSTAD, A. M. G. (1964) 'Thyroid autoimmunization in patients suffering from rheumatoid arthritis and ankylosing spondylitis and in presumably healthy persons', in 'Proc. V Europ. Congr. Rheumatology, Stockholm, 1963', Acta rheum. scand., Suppl. 8, p. 77. 
LIBÁNSKÝ, J., AND Kout, M. (1964) Folia haemat. (Lpz.), 82, 238 (Untersuchungen zur immunologischen Reaktivität bei Hämoblastosen. V. Isohämagglutininwerte bei Leukämien, bösartigen

Lymphomen, Myelomen und Myelofibrosen).

Mollison, P. L. (1967) 'Blood Transfusion in Clinical Medicine', 4th ed. Blackwell, Oxford.

Rawson, A. J., Abelson, N. M., and McCarty, D. J. (1961) Arthr. and Rheum., 4, 463 (The isohemagglutinin partition in rheumatoid arthritis).

SCHIFF, F., AND MeNDlowicz, L. (1926) $Z$. Immunforsch., 48, 1 (Quantitative Untersuchungen über Isoagglutinine mit besonderer Berücksichtigung der Leukämie).

Shohl, J., Morrison, E. G., FAhey, J. L., AND Schmidt, P. J. (1962) J. Lab. clin. Med., 59, 753

(Relation of isohemagglutinin levels to gamma globulin changes in disease).

Teitelbaum, J. I., Wiener, J., AND Desforges, J. F. (1959) Ibid., 53, 535 (A serologic and electrophoretic study of the malignant and proliferative disorders of the hematopoietic and reticuloendothelial systems).

ZüNDEL, W. (1933) Klin. Wschr., 12, 1872 (Blutgruppenbestimmungen speziell bei Blutkrankheiten). 